\title{
Synergistic effects of imatinib and carboplatin on VEGF, PDGF and PDGF-R $\alpha / \beta$ expression in squamous cell carcinoma of the head and neck in vitro
}

\author{
J.D. SCHULTZ ${ }^{1}$, S. ROTUNNO ${ }^{1}$, F. RIEDEL ${ }^{1}$, C. ANDERS ${ }^{1}$, P.ERBEN ${ }^{2}$, R.D. HOFHEINZ ${ }^{2}$, \\ A. FABER ${ }^{1}$, C. THORN ${ }^{1}$, J.U. SOMMER ${ }^{1}$, K. HÖRMANN ${ }^{1}$ and A. SAUTER ${ }^{1}$ \\ Departments of ${ }^{1}$ Otorhinolaryngology, Head and Neck Surgery, and \\ ${ }^{2}$ Hematology and Oncology, University Hospital Mannheim, Germany
}

Received October 19, 2010; Accepted December 16, 2010

DOI: $10.3892 /$ ijo.2011.912

\begin{abstract}
Head and neck squamous cell carcinoma (HNSCC) is an aggressive epithelial malignancy. The development of new treatment modalities in order to improve long-term survival of patients with HNSCC is imperative. Numerous studies have demonstrated that carcinogenesis and tumor cell dissemination is influenced by the tumor microenvironment. The protein-kinase-receptors (PTKs) are essential elements of the intracellular signal transduction pathway and regulate cell growth, development and apoptosis. Cell proliferation, migration, induction of tumor vascularization and carcinogenesis, invasion is regulated by a variety of angiogenic factors, such as PDGF (platelet-derived growth factor), VEGF (vascular endothelial growth factor) and their respective tyrosine kinase receptors (PDGF-R and VEGF-R). They present promising targets for anti-cancer therapy through abrogation of impaired signaling pathways. Indeed, imatinib, a small molecule drug targeting these protein kinases, has antiproliferative effects in several cancer types. The purpose of this study was to investigate the potential synergism of imatinib and carboplatin on the expression of PDGF, PDGF-R $\alpha / \beta$ and VEGF in different HNSCC cell lines. Several tumor cell lines were subjected to increasing concentrations of carboplatin (3 and $7.5 \mu \mathrm{mol} / \mathrm{l})$ and imatinib (18 and $30 \mu \mathrm{mol} / \mathrm{l})$ and ELISA, immunohistochemical methods and RQ-PRC after 48, 72, 120 and $240 \mathrm{~h}$ were used to assess their expression levels. While PDGF-R $\alpha / \beta$ expression was unimpaired at lower imatinib concentrations $(18 \mu \mathrm{mol} / \mathrm{l}), \mathrm{PDGF}-\mathrm{R} \alpha / \beta$ expression was suppressed at $30 \mu \mathrm{mol} / 1$, and suppression was enhanced by the presence of carboplatin. By RQ-PCR, a significant
\end{abstract}

Correspondence to: Dr J.D. Schultz, Univ.-HNO-Klinik, Universitätsmedizin Mannheim, Theodor Kutzer Ufer 1-3, 68167 Mannheim, Germany

E-mail: johannes.schultz@umm.de

Key words: imatinib, carboplatin, vascular endothelial growth factor, platelet-derived growth factor, PDGF-R $\alpha / \beta$, head and neck squamous cell carcinoma, protein-tyrosin-kinase reduction of PDGF-R $\alpha / \beta$ expression was detected $(\mathrm{p}<0.5)$. We observed explicit significant reduction in VEGF levels with increasing concentrations of imatinib and with the combination of the two chemotherapeutic drugs $(p<0.5)$. We report for the first time evidence of synergism of imatinib and carboplatin in suppressing VEGF, PDGF and PDGF-R $\alpha / \beta$ expression in HNSCC.

\section{Introduction}

Head and neck squamous cell carcinoma (HNSCC) is an aggressive epithelial malignancy known to be the most common neoplasm arising in the upper aerodigestiv tract. With a global annual incidence of approximately 644,000 cases and 352,000 HNSCC-associated deaths, squamous cell carcinoma of the head and neck (HNSCC) is the fifth most common cancer worldwide $(1,2)$. The poor five-year survival rate has remained unchanged in the last decades, despite improved techniques in surgery, and the radiation and chemotherapy established (3). Thus, the development of new treatment modalities in order to improve long-term survival of patients with HNSCC is imperative.

Promotion of tumor growth, angiogenesis and invasion of HNSCC is attributed to different cell types populating the tumor stroma, such as endothelial cells, cancer-associated fibroblasts (CAFs), pericytes and infiltrating inflammatory cells. These cell types are implicated as functionally important for carcinogenesis by providing proliferative and anti-apoptotic regulatory factors leading to tumor angiogenesis, and facilitating invasion (4-9). Various studies could demonstrate the fundamental role of a concerted performance of genetically altered tumor cells interacting with ostensibly normal cell types in carcinogenesis. These factors and their interaction constitute the tumor microenvironment (10).

A variety of angiogenic peptides, such as VEGF (vascular endothelial growth factor), PDGF (platelet-derived growth factor), released from tumor cells and macrophages regulate the induction of the tumor vascularization. Various functions, including endothelial cell migration, proliferation and capillary tubule formation are performed by these factors. 
Platelet-derived growth factor (PDGF). One of the detected factors providing this cellular interaction and phenotypic character of the CAFs is platelet-derived growth factor (PDGF) $(6,8,11)$. The involvement of the different isoforms of PDGF plays a decisive role in regulating cell proliferation, chemotaxis and survival in normal cells as well as in the process of tumorigenesis by autocrine and paracrine stimulation (12-14). The biological activity of the different compounds of the PDGF family, characterized by the polypeptide chains $\mathrm{A}, \mathrm{B}, \mathrm{C}, \mathrm{D}$, forming the homodimer AA, BB, CC, DD and heterodimers $\mathrm{AB}$, is based on the association with the tyrosine kinase receptors, PDGF- $\alpha$ and $-\beta$ receptors (15). Upon binding of PDGF to its cognate receptor, receptor tyrosine kinase activity is induced through receptor dimerisation and subsequent autophosphorylation. Active PDGF-R induces signaling molecules that conduct to the different biological effects of PDGF mentioned above $(16,17)$, such as MAP kinase (mitogen-activated protein kinases) or ras/raf (family of three serine/threonine-specific protein kinases)/MEK/ERK (extracellular-signal-regulated kinases) signaling.

Previous studies demonstrated the upregulated expression of PDGF and the associated receptors in various malignant human tumors such as non-small cell lung (18) and prostate cancer (14). PDGF promotes vascularization of stroma and therefore tumor proliferation $(19,20)$ in melanoma (21), fibrosarcoma (22), breast (23) and squamous carcinoma (24). Many additional angiogenic factors have been identified including vascular endothelial growth factor (VEGF) (25).

Vascular endothelial growth factor (VEGF). VEGF is a potent endothelial mitogen factor that also promotes angiogenesis and enhances vascular permeability (26). Its overexpression is associated with enhanced tumor growth and angiogenesis in a mouse model (27) as well as in various malignant human tumors including HNSCC (28-30). Furthermore, Riedel et al demonstrated raised VEGF serum levels in HNSCC patients compared with healthy subjects (31). Angiogenesis induced by VEGF overexpression in HNSCC tumors is inversely correlated with inhibition of apoptosis $(32,33)$, illustrating the anti-apoptotic potential of VEGF. Inhibition of angiogenesis by blocking these angiogenic cytokines or their pathways has become a major target in experimental cancer therapies.

Protein-tyrosine-kinase-receptors (PTKs) are essential elements of the intracellular signal transduction pathway, which regulate cell growth, development and apoptosis, which in case of mutations in different types of cancer often cause disruption of normal cell signaling pathways and might lead to malignant transformation (34). For example mutations in PTKs lead to a constitutively activition ot the downstream signaling.

Imatinib (STI571). The tyrosine kinase inhibitor imatinib $\left(\right.$ Gleevec $\left.^{\circledR}\right)$, also known as STI571, manufactured by Novartis, Basel, Switzerland), is a small molecule drug of the 2-phenylaminopyrimidine class. It is a potent inhibitor of bcr-abl (abelson murine leukemia viral oncogene homolog), c-kit (CD117) and PGDF-R, initially used in the treatment of chronic myeloid leukemia (CML) (35-38).

The ability of imatinib to target specific tyrosine kinases, which are implicated in tumorigenesis and metastasis, makes it an ideal therapeutic agent with few associated side-effects. The drug is currently used in a limited number of cancers such as gastrointestinal stromal tumors, melanomas and various forms of lung cancer $(39,40)$. Indeed several studies have demonstrated the proapoptotic effects of imatinib, and thus it was subsequently evaluated in concert with chemotherapeutics acting through distinct mechanism, such as those derived from cisplatin family.

Prior studies suggested a potential synergism upon the co-administration of imatinib and cisplatin, through their abilities of targeting distinct cell-proliferative functions and were shown to enhance the therapeutic ratio (41), our study is the first to our knowledge evaluating the potential synergism of imatinib and carboplatin for HNSCC.

Synergism with platin-based chemotherapy. Imatinib shows synergistic effects concerning growth inhibition with the established chemotherapeutic substances in leukemia and in adenocarcinomas $(42,43)$. Zhang et al showed synergistic effects leading to an increased growth inhibition of the simultaneous treatment of NSCLS (non-small-cell lung cancer) with cisplatin and imatinib (44). Iain et al allocate this statistically significant interaction between these two drugs concerning the growth inhibitory effects for HNSCC (45). The hypothesis of the mechanism of the synergy postulates that imatinib delays DNA (deoxyribonucleic acid) cross-link repair induced by cisplatin. Furthermore, imatinib has been reported to alter the balance between pro- and antiapoptotic factors by upregulating pro-apoptotic BCL-2 (B-cell lymphoma), one member of apoptosis regulators $(46,47)$. The observed synergy in the literature may be caused by the effect of imatinib on the repair of DNA damage and consequently maintaining or enhancing the molecular triggers that initiate cell death pathways. The explicit underlying mechanism of the synergism still remains unclear.

Carboplatin, cis-diammine [cyclobutane-1,1-dicarboxylate-O,O')platinum(II)], is one of the most important drugs for the treatment of head and neck cancer. The molecular mechanism of carboplatin in inhibiting cell growth is through the formation of intrastrand crosslinked adducts of DNA. DNA crosslinking causes abrogation of DNA synthesis, suppression of RNA (ribonucleic acid) synthesis, leading to cell cycle perturbation and induction of tumor suppressor genes such as p53 (tumor protein 53) and p73 (tumor protein 73) (49). Thus, widespread DNA damage caused by carboplatin ultimately initiates various apoptotic signaling pathways, leading to cell death and reduction of tumor growth (48). This cytotoxic profile has made carboplatin one of the most successful chemotherapeutic agents for a number of cancers.

The purpose of this study was to evaluate synergistic effects of imatinib, both alone and in combination with carboplatin, as an established chemotherapeutic agent in HNSCC treatment, on the expression of VEGF, PDGF $\alpha$ and the corresponding receptors, PDGF-R $\alpha / \beta$ in vitro. To our knowledge, this is the first report of a chemotherapeutic study treating HNSCC with imatinib and carboplatin.

\section{Materials and methods}

Cell lines. The HNSCC cell lines 11B, 14C and 22B were obtained from Dr T.E. Carey (University of Michigan, MI, USA). They originate from human HNSCC of the oro- and hypopharynx and larynx. Cell cultures were grown at $37^{\circ} \mathrm{C}$ in 
a fully humidified atmosphere with $5 \% \mathrm{CO}_{2}$ using Dulbecco's modified minimum essential medium (DMEM) (Fisher Scientific Co., Pittsburgh, PA, USA) containing $10 \%$ fetal calf serum (FCS) and antibiotics (Life Technologies Inc., Gainthersburg, MD, USA). Imatinib was kindly provided by the manufacturer (Novartis). Imatinib and carboplatin were stored at $4^{\circ} \mathrm{C}$ and dissolved in sterile water before use. The HNSCC cell lines were subjected to different concentrations of imatinib (18 and $30 \mu \mathrm{mol} / \mathrm{l}$ ) and/or carboplatin (3 and $7.5 \mu \mathrm{mol}$ ) and grown for 2, 3, 5 and 10 days. Drug concentrations were chosen based on AlamarBlue (AbD Serotec Oxford, UK) cell proliferation assay, which quantitatively measures proliferation of HNSCC tumor cell lines in response of the chemotherapeutic drug and its concentration. After the incubation period the supernatants were collected and stored at $-20^{\circ} \mathrm{C}$ until further analysis. After harvesting the cells through centrifugation of the suspension cell lines, cells were stored at $-80^{\circ} \mathrm{C}$ for PCR (polymerase chain reaction) analysis.

Immunohistochemistry of PDGF-A/B ligand. Immunohistochemical studies were performed using a monoclonal rabbit antibody directed against human PDGF-A/B (ACRIS Antibodies, Herford, Germany). The cells were cultured overnight on glass coverslips (Nunc, Wiesbaden, Germany) before immunohistochemistry was done. When $50 \%$ confluent, cells were exposed to the chemotherapeutics for different time periods as described above and subsequently fixed with acetone and alcohol (2:1). After washing the cells with PBS (phosphate-buffered saline) the samples were incubated with the peroxidase block (Dako Hamburg, Germany) for $30 \mathrm{~min}$. Following further PBS washes ( $3 \times 5 \mathrm{~min})$. Cells were incubated with $10 \%$ normal sheep serum for $30 \mathrm{~min}$. Cells were exposed to the rabbit monoclonal antibody against PDGF-A/B for $30 \mathrm{~min}$ at room temperature 1:100 (ACRIS Antibodies). The incubated cell lines were cooled overnight at $4^{\circ} \mathrm{C}$. Afterwards the cells were washed with PBS as before and incubated with secondary antibody (1:100) (anti-rabbit, Amersham, Freiburg, Germany) for $45 \mathrm{~min}$ at room temperature. The incubation was followed by a three-times washing procedure. Strepavidin HRP (horseradish peroxidase)-conjugated secondary antibody was detected by AEC (aminoehtylcarbazole red) or DAB (diaminobenzidine brown) as chromogen and incubated for 5-15 min. After blocking of endogenous peroxidase, cells were washed various times. Finally sections received a counterstaining with Harris' hematoxylin for $30 \mathrm{sec}$. This procedure was followed by coverslipping.

The results of the observed immunohistochemical rates of PDGF expression were determined semi-quantitatively. The stain intensity was as follows: strong reactivity, $>80 \%$ of the cells were positive; moderate reactivity, $50-80 \%$ of the cells stained positive; weak reactivity, $<50 \%$ of the cells were positive; and negative immunostained cells ( $0 \%$ reactivity).

ELISA total PDGF-R $\alpha / \beta$ (receptor) and VEGF (ligand). Cells having been exposed to the different chemotherapeutics at their respective concentrations as described above were also rinsed with $\mathrm{PBS}$ and then lysed using lysis buffer under gently vortexing at $2-8^{\circ} \mathrm{C}$ for $30 \mathrm{~min}$. Cell debris was separated by centrifugation $(14,000 \mathrm{x} \mathrm{g}$ for $5 \mathrm{~min})$ and supernatant was kept for further analysis.
VEGF concentrations were determined by ELISA (enzymelinked immunosorbent assay) (R\&D Systems, Wiesbaden, Germany). The system used a solid-phase monoclonal antibody directed against VEGF and an enzyme-linked polyclonal antibody, raised against recombinant VEGF165. The specificity of anti-human VEGF antibodies used in the ELISA kit was examined by sodium dodecylsulphate polyacrylamide gel electrophoresis (SDS-PAGE) followed by Western blotting. According to the manufacturer's directions, each ELISA assay measured $100 \mu \mathrm{l}$ of supernatant. All analyses and calibrations were carried out in duplicate. The calibrations on each microtiter plate included recombinant human VEGF standards provided in the kit. Optical density was determined using a micro-plate reader at a wavelength of $450 \mathrm{~nm}$. Wavelength correction was set to $540 \mathrm{~nm}$ and concentrations were reported as $\mathrm{pg} / \mathrm{ml}$. The variability between assays as reported by the manufacturer ranged from 6.2 to $8.8 \%$ when VEGF concentrations were between 50 and $1000 \mathrm{pg} / \mathrm{ml}$.

The DouSet IC ELISA (R\&D Systems) measures human PDGF-R $\alpha / \beta$ by development of a sandwich ELISA with an immobilized capture antibody specific for human PDGF-R, which binds both tyrosin-phosphorylated and unphosphorylated PDGF-R. After washing away the unbound material, a biotinylated detection antibody specific for total human PDGF-R is used to detect tyrosin-phosphorylated and unphosphorylated PDGF-R, utilizing a standard strepavidin-HRP format.

The capture antibody was diluted to the concentration 1:180 $(4 \mu \mathrm{g} / \mathrm{ml})$. The diluted capture antibody was carried out $100 \mu \mathrm{l}$ per well and the plate was sealed and incubated overnight. Afterwards three times aspiration and washing of each well with $400 \mu \mathrm{l}$ tween wash buffer. Adjacent plates were blocked by adding $300 \mu \mathrm{l}$ of block buffer to each well and incubated at room temperature for 1-2 h. According to the manufacturer's directions, each ELISA assay measured $100 \mu \mathrm{l}$ of supernatant of the sample. Washing was repeated with tween buffer as described. After having diluted the detection antibody to a concentration of $500 \mathrm{ng} / \mathrm{ml}, 100 \mu \mathrm{l}$ of this was added to each well with an incubation period of $2 \mathrm{~h}$. Again cells were washed and $100 \mu \mathrm{g}$ streptavidin-HRP were added to each well and incubated for $20 \mathrm{~min}$ at room temperature. Afterwards $100 \mu \mathrm{l}$ substrate solution was added for $20 \mathrm{~min}$ followed by $50 \mu \mathrm{l}$ stop solution to each well. Optical density was determined using a micro-plate reader at a wavelength of $450 \mathrm{~nm}$. Wavelength correction was set to $540 \mathrm{~nm}$ and concentrations were reported as $\mathrm{pg} / \mathrm{ml}$. All analyses and calibrations were carried out in duplicate.

RNA extraction and $c D N A$ synthesis. After distributing the tumor cell lines in 6-well chambers and after reaching 50\% confluence, the cells were exposed to the different drug concentrations for up to 10 days.

Total RNA was extracted after homogenization of 15-30 mg tissue with the Ultra Turrax Tube Drive (Ika, Staufen, Germany) using TRIzol reagent (Invitrogen, Karlsruhe, Germany) according to the manufacturer's instructions. A sample of $5 \mathrm{mg}$ of total RNA was reverse transcribed using random hexamer priming and Moloney murine leukemia virus reverse transcriptase (Invitrogen). After that RNA extraction of all frozen samples and reverse transcription to cDNA was performed. 
Table I. PDGF-R $\alpha / \beta$ oligonucleotides used for RQ-PCR assays and cloning of the plasmid standard.

\begin{tabular}{|c|c|c|c|}
\hline Assay & & Name & Sequences 5'-3' \\
\hline $\begin{array}{l}\text { PDGF-R } \alpha \\
\text { quantification }\end{array}$ & LightCycler primer & PDA12 & CCAAGAGATGGACTAGTGCTTG \\
\hline $\begin{array}{l}\text { PDGF-R } \alpha \\
\text { quantification }\end{array}$ & LightCycler primer & PDA15 & TAGCTCCGTGTGCTTTCATCAG \\
\hline $\begin{array}{l}\text { PDGF-R } \alpha \\
\text { quantification }\end{array}$ & $\begin{array}{l}\text { LightCycler hybridisation } \\
\text { probe }\end{array}$ & PDA15FL & $\begin{array}{l}\text { GAATAGGGATAGCTTCCTGAGCCACCA- } \\
\text { Fluorescein }\end{array}$ \\
\hline $\begin{array}{l}\text { PDGF-R } \alpha \\
\text { quantification }\end{array}$ & $\begin{array}{l}\text { LightCycler hybridisation } \\
\text { probe }\end{array}$ & PDA15LC & $\begin{array}{l}\text { LCRED640- } \\
\text { CCAGAGAAGCCAAAGAAAGAGCTGGA }\end{array}$ \\
\hline $\begin{array}{l}\text { PDGF-R } \beta \\
\text { quantification }\end{array}$ & LightCycler primer & PDB13F & CGTCAAGATGCTTAAATCCACAGC \\
\hline $\begin{array}{l}\text { PDGF-Rß } \\
\text { quantification }\end{array}$ & LightCycler primer & PDB15R & TGATGATATAGATGGGTCCTCCTTTG \\
\hline $\begin{array}{l}\text { PDGF-Rß } \\
\text { quantification }\end{array}$ & $\begin{array}{l}\text { LightCycler hybridisation } \\
\text { probe }\end{array}$ & PDB14FL & $\begin{array}{l}\text { GCTGAAGATCATGAGTCACCTTGGGC- } \\
\text { Fluorescein }\end{array}$ \\
\hline $\begin{array}{l}\text { PDGF-Rß } \\
\text { quantification }\end{array}$ & $\begin{array}{l}\text { LightCycler hybridisation } \\
\text { probe }\end{array}$ & PDB14LC & $\begin{array}{l}\text { LCRED640- } \\
\text { CCACCTGAACGTGGTCAACCTGTTG }\end{array}$ \\
\hline $\begin{array}{l}\text { PDGF-Rß } \\
\text { quantification }\end{array}$ & LightCycler primer & PDB9F & GAGACCTCAAAAGGTGTCCACG \\
\hline
\end{tabular}

Real-time quantitative reverse transcriptase polymerase chain reaction $(R Q-P C R)$. Expression analysis of $\mathrm{PDGF}-\mathrm{R} \alpha, \mathrm{PDGF}-\mathrm{R} \beta$ was performed as described (51). VEGF-A and VEGF-B expression analysis was executed using the LightCycler instrument 1.5 (Roche Diagnostics, Mannheim, Germany). Each 20- $\mu 1$ reaction mix contained $4 \mu \mathrm{l}$ LightCycler Faststart DNA Masterplus Hyb Probes master mix (Roche Diagnostics), $2 \mu 1$ cDNA template or plasmid dilution, $0.5 \mu \mathrm{M}$ forward primers and $0.5 \mu \mathrm{M}$ reverse primer $0.25 \mu \mathrm{M}$ anchor probe and $0.25 \mu \mathrm{M}$ sensor probe (TIB Molbiol, Berlin, Germany). The primer and probe sequences are shown in Table I. Cycler conditions were the following: $10 \mathrm{~min}$ denaturation at $95^{\circ} \mathrm{C}, 50$ cycles of $10 \mathrm{sec}$ at $59 / 60^{\circ} \mathrm{C}$ (annealing PDGFRA and PDGFRB/ VEGFR, VEGF) and $26 \mathrm{sec}$ at $72^{\circ} \mathrm{C}$ (elongation). A 5-log series of plasmid dilutions (see below) was amplified within the PCR runs for quantification of PDGFRA, PDGFRB. B-glucuronidase (GUS) mRNA (messenger ribonucleic acid) was quantified as internal control as previously described (51). The LightCycler software prepares standard curves using linear regression analysis of the plasmid dilutions and calculates copy numbers of the unknown sample (51).

Cloning of quantification standards. For plasmid preparation, nested or single-step RT-PCR (real-time polymerase chain reaction) products from sequences (PDGFRA, PDGFRB), were amplified from cell lines (HL-60, or SW480) (primers Table I). The Expand high fidelity plus PCR system ${ }^{\mathrm{TM}}$ (Roche Diagnostics) was used. PCR transcripts were cloned into the PCR2.1-TOPO vector and introduced into $E$. coli TOP10F' according to the manufacturers' instructions (Invitrogen). Plasmid DNA containing the desired construct was isolated using the Plasmid Midi and Maxi Kit ${ }^{\mathrm{TM}}$ (Qiagen, Hilden,
Germany) and inserts were confirmed by bidirectional direct sequencing. The resulting plasmid was linearised by $\mathrm{Xba \textrm {I }}$ digestion at $37^{\circ} \mathrm{C}$ for $2 \mathrm{~h}$ followed by heat inactivation at $65^{\circ} \mathrm{C}$ for $20 \mathrm{~min}$. GUS mRNA transcripts were measured as internal control using a standard plasmid (pME-2) containing BCR-ABL (breakpoint cluster region), ABL (abelson murine leukemia viral oncogene homolog), and GUS sequences (56). Dilutions of the linearised plasmid were prepared in $10 \mathrm{mM}$ Tris-HCl pH 8.0; 1 mM EDTA containing $20 \mu \mathrm{g} / \mathrm{ml}$ tRNA (transfer ribonucleic acid) (Roche Diagnostics).

Statistical analysis. Statistical analysis was performed in collaboration with Dr Chr. Weiss, Institute of Biomathematics, Faculty of Medicine, Mannheim. All data were subjected to the Means procedure. $\mathrm{p} \leq 0.05$ was considered statistically significant. The statistical test was the two coefficient variance analysis and the Dunnett's-test.

\section{Results}

In order to analyse the effect of carboplatin and imatinib on HNSCC cell lines, we added two concentrations of imatinib (18 and $30 \mu \mathrm{mol} / \mathrm{l}$ ) and carboplatin (3 and $7.5 \mu \mathrm{mol} / 1)$. PDGF, PDGF-R $\alpha / \beta$ and VEGF expression in the supernatants of HNSCC the cell lines were assessed by ELISA, immunohistochemical methods and RQ-PCR after 2, 3, 5 and 10 days post addition of the chemotherapeutic.

Immunohistochemistry for PDGF- $\alpha$ (ligand). The results of the immunohistochemically observed rates of expression were determined semi-quantitatively. The immunohistochemical studies against PDGF- $\alpha$ showed decreased reactivity with 
Table II. Grading of immunostaining for PDGF- $\alpha .^{\mathrm{a}}$

\begin{tabular}{|c|c|c|c|c|}
\hline Immunostaining index & $48 \mathrm{~h}$ & $72 \mathrm{~h}$ & $120 \mathrm{~h}$ & $240 \mathrm{~h}$ \\
\hline Control group & $++(3 / 3)$ & $\begin{array}{r}++(2 / 3) \\
+++(1 / 3)\end{array}$ & $\begin{array}{r}++(2 / 3) \\
+++(1 / 3)\end{array}$ & $+++(3 / 3)$ \\
\hline Carboplatin $3 \mu \mathrm{mol}$ & $\begin{array}{r}+(1 / 3) \\
++(2 / 3)\end{array}$ & $\begin{array}{r}++(2 / 3) \\
++(1 / 3) \\
+++(1 / 3)\end{array}$ & $\begin{array}{r}++(2 / 3) \\
+++(1 / 3)\end{array}$ & $\begin{array}{r}++(1 / 3) \\
+++(2 / 3)\end{array}$ \\
\hline Carboplatin $7.5 \mu \mathrm{mol}$ & $\begin{array}{l}++(2 / 3) \\
++(2 / 3)\end{array}$ & $\begin{array}{r}+(2 / 3) \\
+++(2 / 3)\end{array}$ & $\begin{array}{r}+(2 / 3) \\
++(1 / 3)\end{array}$ & $\begin{array}{l}+++(2 / 3) \\
+++(1 / 3)\end{array}$ \\
\hline Imatinib $18 \mu \mathrm{mol}$ & $\begin{array}{r}+(2 / 3) \\
++(1 / 3)\end{array}$ & $\begin{array}{r}+(2 / 3) \\
++(1 / 3)\end{array}$ & $\begin{array}{l}++(1 / 3) \\
++(1 / 3) \\
++(1 / 3)\end{array}$ & $\begin{array}{l}++(1 / 3) \\
++(2 / 3)\end{array}$ \\
\hline Imatinib $30 \mu \mathrm{mol}$ & $\begin{array}{l}+(1 / 3) \\
+(2 / 3)\end{array}$ & $\begin{array}{l}0(1 / 3) \\
+(2 / 3)\end{array}$ & $\begin{array}{l}0(1 / 3) \\
+(2 / 3)\end{array}$ & $\begin{array}{r}0(1 / 3) \\
+(1 / 3) \\
+++(1 / 3)\end{array}$ \\
\hline $\begin{array}{l}\text { Carboplatin } 3 \mu \mathrm{mol}+ \\
\text { imatinib } 18 \mu \mathrm{mol}\end{array}$ & $\begin{array}{l}+(2 / 3) \\
+(1 / 3)\end{array}$ & $\begin{array}{l}+(2 / 3) \\
+(0 / 3)\end{array}$ & $\begin{array}{r}+(1 / 3) \\
++(2 / 3)\end{array}$ & $\begin{array}{r}+(2 / 3) \\
++(1 / 3)\end{array}$ \\
\hline $\begin{array}{l}\text { Carboplatin } 7.5 \mu \mathrm{mol}+ \\
\text { imatinib } 30 \mu \mathrm{mol}\end{array}$ & $+(2 / 3)$ & $\begin{array}{l}+(2 / 3) \\
+(1 / 3)\end{array}$ & $0(1 / 3)$ & $0(1 / 3)$ \\
\hline
\end{tabular}

${ }^{a} 0$, no positive cells; 1 , weak immunostaining; 2 , moderate immunostaining; 3 , strong immunostaining. (x/3), number of positive cell lines out of the UMSCC lines $14 \mathrm{C}, 11 \mathrm{~B}$ and $22 \mathrm{~B}$.

rising concentrations of carboplatin or imatinib, respectively and reactivity decreased the longer the incubation period was. By contrast the controls showed high reactivity against PDGF- $\alpha$ independent to the length of incubation time. The immunostaining was localized to the cytoplasm of the cells (Fig. 1, Table II).

ELISA for PDGF-R $\alpha / \beta$ of HNSCC $11 B, 14 C, 22 B$. To determine the effect of carboplatin and imatinib, as well as the combination of these chemotherapeutic agents on PDGF-R of HNSCC 11B, 14C and 22B cells, we added different concentrations of imatinib (18 and $30 \mu \mathrm{mol} / \mathrm{l})$ and carboplatin (3 and $7.5 \mu \mathrm{mol} / \mathrm{l}$ ). To quantify cytosolic expression of PDGF$\mathrm{R} \alpha / \beta$ as well as VEGF (ligand) secretion of the supernatant of HNSCC, cell lines were treated with either non-containing (control group) or imatinib and/or carboplatin containing medium.

PDGF-R $\alpha / \beta$ levels showed a consistent trend towards a decreased expression according to the treatment with rising drug concentration and extension of incubation period, as well as the type of the agent (Table III).

ELISA of PDGF-R $\alpha$. For HNSCC $11 \mathrm{~B}$ a maximal reduction of PDGF-R $\alpha$ expression at $7.5 \mu \mathrm{mol} / 1$ carboplatin after $240 \mathrm{~h}(172 \mathrm{pg} / \mathrm{ml}$; negative control $308 \mathrm{pg} / \mathrm{ml})$ and imatinib (30 $\mu \mathrm{mol} / \mathrm{l})$ after $240 \mathrm{~h}(107.46 \mathrm{pg} / \mathrm{ml}$; negative control $308 \mathrm{pg} / \mathrm{ml}$ ) was detected. The combination of carboplatin and imatinib induced no further reduction of PDGF-R $\alpha$ level (after 240 h, $218 \mathrm{pg} / \mathrm{ml} ; 181 \mathrm{pg} / \mathrm{ml}$, respectively). The level of significance was $\mathrm{p}=0.56$.

HNSCC $14 \mathrm{C}$ cell lines proved to be less vulnerable towards the drug in that a noticeable reduction of PDGF- $\alpha$ could only be proven for carboplatin/imatinib $(3 \mu \mathrm{mol} / 1+18 \mu \mathrm{mol} / 1$ after $72,120,240 \mathrm{~h})\left(\mathrm{cPDGF}_{72 \mathrm{~h}}=13 \mathrm{pg} / \mathrm{ml} / \mathrm{cPDGF}_{\text {control72h }}=\right.$ $226 \mathrm{pg} / \mathrm{ml} ; \mathrm{cPDGF}_{120 \mathrm{~h}}=27 \mathrm{pg} / \mathrm{ml} / \mathrm{cPDGF}_{\text {control } 120 \mathrm{~h}}=85 \mathrm{pg} / \mathrm{ml}$; $\left.\mathrm{cPDGF}_{240 \mathrm{~h}}=49 \mathrm{pg} / \mathrm{ml} / \mathrm{cPDGF}_{\text {control } 240 \mathrm{~h}}=122 \mathrm{pg} / \mathrm{ml}\right)$.

The maximal concentration of $7.5 \mu \mathrm{mol} / 1$ carboplatin + $30 \mu \mathrm{mol} / 1$ imatinib showed the following expression rates after 72 and $120 \mathrm{~h}\left(\mathrm{cPDGF}_{72 \mathrm{~h}}=6 \mathrm{pg} / \mathrm{ml} / \mathrm{cPDGF}_{\text {control72h }}=\right.$ $\left.226 \mathrm{pg} / \mathrm{ml} ; \mathrm{cPDGF}_{120 \mathrm{~h}}=27 \mathrm{pg} / \mathrm{ml} / \mathrm{cPDGF}_{\text {control } 120 \mathrm{~h}}=85 \mathrm{pg} / \mathrm{ml}\right)$, not statistically significant $(\mathrm{p}=0.77)$. Single-drug exposure showed less consequence on the PDGF-R $\alpha$ level.

For HNSCC 22B there was no significant reduction in PDGF-R $\alpha$ expression detectable $(\mathrm{p}=0.25)$. There was evidence of decreasing PDGF-R $\alpha$ levels with increasing concentrations of imatinib (single-drug application of $18 \mu \mathrm{mol} /)\left(\mathrm{cPDGF}_{72 \mathrm{~h}}\right.$ $=293 \mathrm{pg} / \mathrm{ml} ; \mathrm{cPDGF}_{120 \mathrm{~h}}=136 \mathrm{pg} / \mathrm{ml}$ and for $30 \mu \mathrm{mol} / \mathrm{l}$ $\mathrm{cPDGF}_{72 \mathrm{~h}}=339 \mathrm{pg} / \mathrm{ml} ; \mathrm{cPDGF}_{120 \mathrm{~h}}=34 \mathrm{pg} / \mathrm{ml} ; \mathrm{cPDGF}_{240 \mathrm{~h}}$ $=20 \mathrm{pg} / \mathrm{ml})$ and the combination of imatinib/carboplatin $(18+3.5 \mu \mathrm{mol} / 1$ and $30+7.5 \mu \mathrm{mol} / \mathrm{l})$ after 72,120 and $240 \mathrm{~h}$. Whereas carboplatin as single-active drug did not show influence on PDGF-R $\alpha$ level.

ELISA of PDGF-Rß. Application of carboplatin $3 \mu \mathrm{mol} / \mathrm{l}$ and increase of the dosage to $7.5 \mu \mathrm{mol} / 1$ leads to a non-significant reduction $(\mathrm{p}=0.28)$ of PDGF-Rß level after $24 \mathrm{~h}$ for HNSCC 11B. Conversely, exposure to imatinib caused a consistent reduction even after $120 \mathrm{~h}$. The combination of both agents confirms this consistent trend of decreased PDGF-R $\beta$ $(7.5+30 \mu \mathrm{mol} / \mathrm{l})\left(\mathrm{cPDGF}-\mathrm{R} \beta_{120 \mathrm{~h}}=14 \mathrm{pg} / \mathrm{ml} / \mathrm{cPDGF}-\mathrm{R} \beta_{\text {control } 120 \mathrm{~h}}\right.$ $=28 \mathrm{pg} / \mathrm{ml} ; \mathrm{cPDGF}-\mathrm{R} \beta_{240 \mathrm{~h}}=12 \mathrm{pg} / \mathrm{ml} / \mathrm{cPDGF}-\mathrm{R} \beta_{\text {control } 240 \mathrm{~h}}=$ $34 \mathrm{pg} / \mathrm{ml})$.

Within the timeframe of 48-78 $\mathrm{h}$, there was evidence for a reduction of an PDGF-Rß expression in HNSCC 14C by 


\section{Immunohistochemistry for PDGF- $\alpha$}

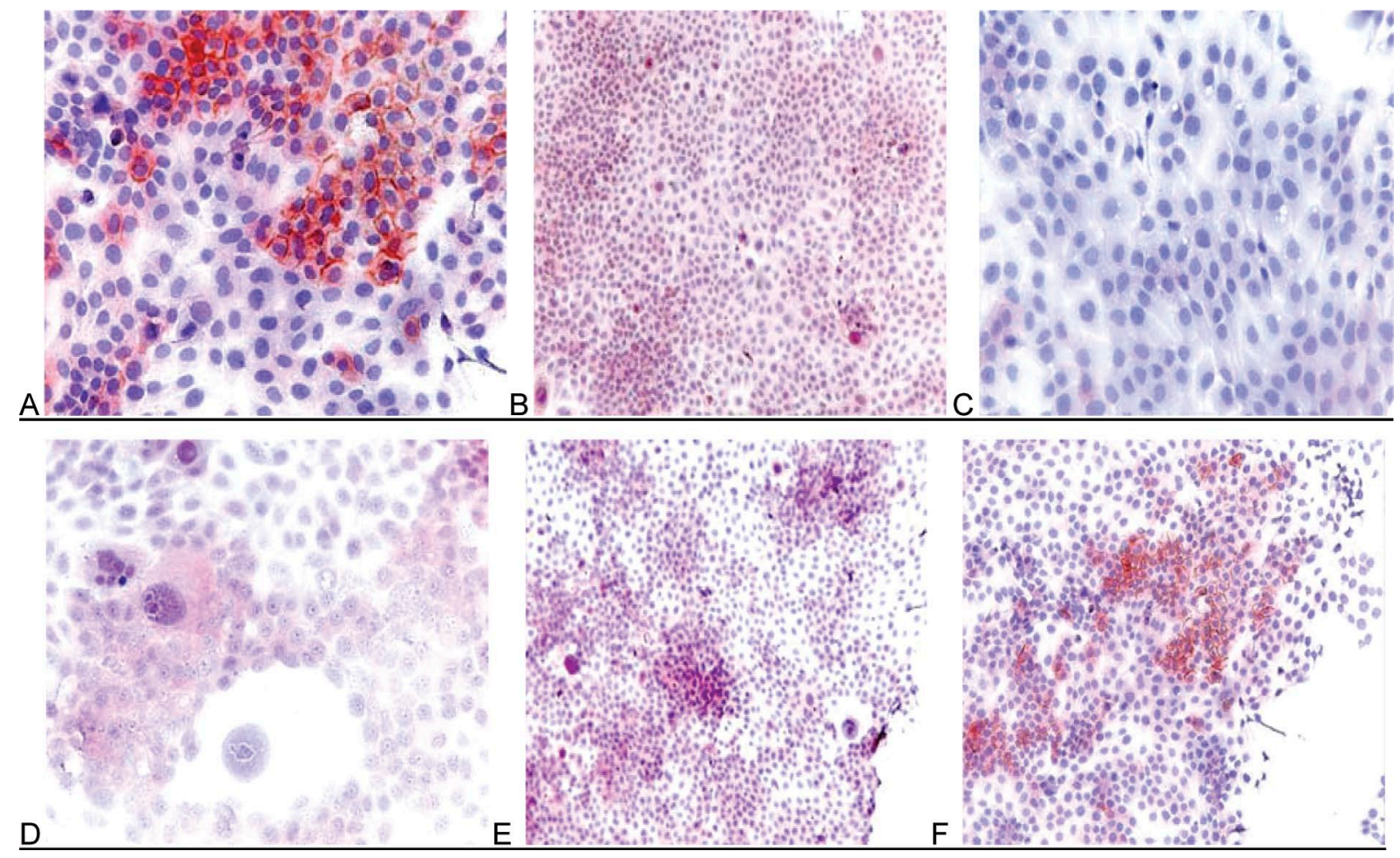

Figure 1. Immunohistochemistry for PDGF- $\alpha$ expression; (A and B) Positive immunohistochemical reactivity against PDGF- $\alpha$ (x20) after incubation with carboplatin and imatinib $(3+18 \mu \mathrm{mol})$ after $48 \mathrm{~h}$. (C and D) Positive immunohistochemical reactivity against PDGF- $\alpha$ (x20-40) with carboplatin and imatinib $(7.5+30 \mu \mathrm{mol})$ after $120 \mathrm{~h}$. (E-F) Control group with strong immunoreactivity.

\section{HNSCC-14C-PDGF- $B$}

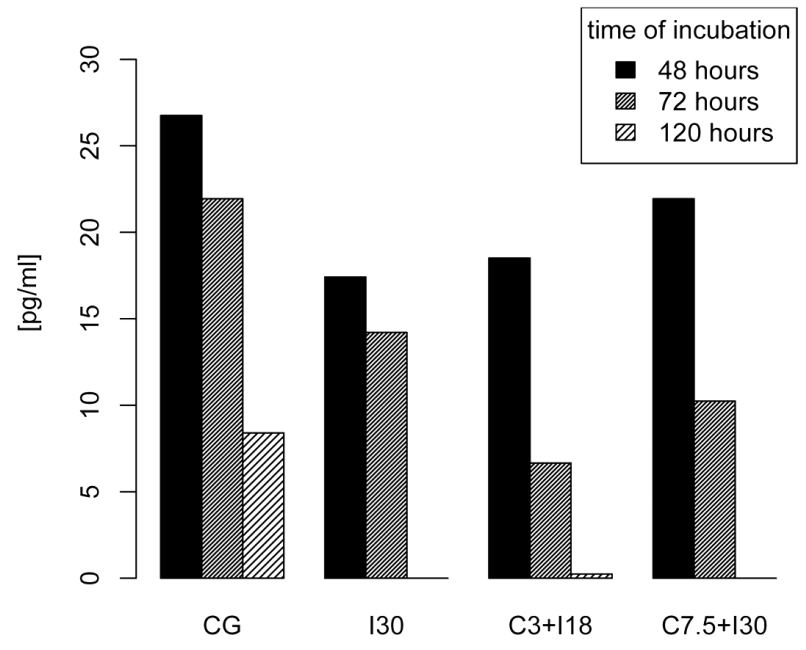

Figure 2. ELISA methods; PDGF-Rß expression in HNSCC 14C. Decreased expression of PDGF-Rß with rising concentrations of the applicated drugs (C, carboplatin; I, imatinib; CG, control group) after incubation periods of $48-120 \mathrm{~h}(\mathrm{p}=0.2)$.

imatinib compared to the controls (imatinib $30 \mu \mathrm{mol} / \mathrm{l}$ ) (cPDGF$\mathrm{R} \beta_{48 \mathrm{~h}}=17 / \mathrm{cPDGF}-\mathrm{R} \beta_{\text {control48h }}=26 \mathrm{pg} / \mathrm{ml} ; \mathrm{cPDGF}-\mathrm{R} \beta_{72 \mathrm{~h}}=14 \mathrm{pg} /$ $\mathrm{ml} / \mathrm{cPDGF}-\mathrm{R} \beta_{\text {control72h }}=21 \mathrm{pg} / \mathrm{ml} ; \mathrm{cPDGF}-\mathrm{R} \beta_{120 \mathrm{~h}}=0.5 \mathrm{pg} / \mathrm{ml} /$ $\left.\mathrm{cPDGF}-\mathrm{R} \beta_{\text {control 120h }}=8 \mathrm{pg} / \mathrm{ml}\right)$. In contrast, carboplatin had no influence on the PDGF-Rß level. The simultaneous incubation with imatinib and carboplatin seemed to be much more efficient in lowering the measured PDGF-Rß concentration
HNSCC-22B-PDGF- $B$

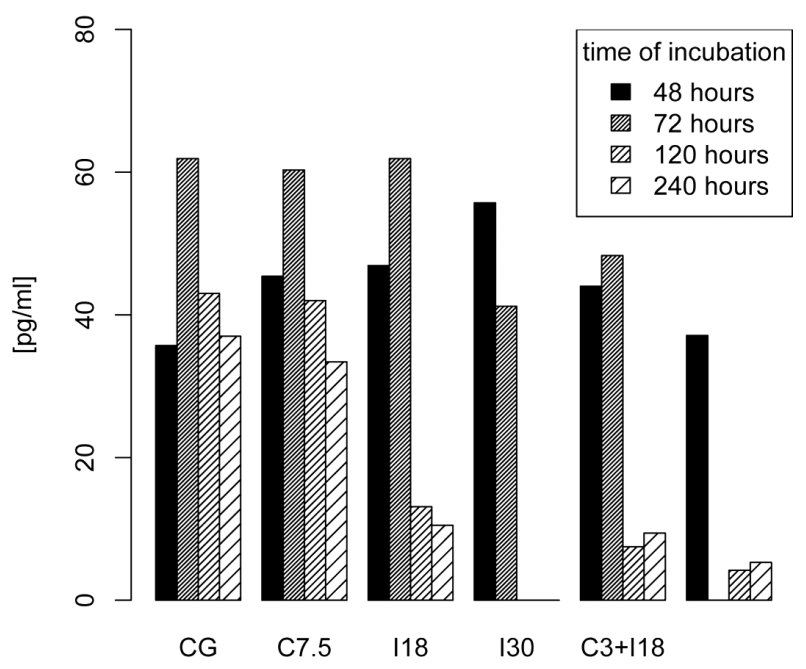

Figure 3. ELISA methods for PDGF-Rß expression in HNSCC 22B. Decreased expression of PDGF-Rß with rising concentrations of the applicated drugs (C, carboplatin; I, imatinib; CG, control group) after incubation periods of $48-240 \mathrm{~h}(\mathrm{p}=0.32)$.

measured as imatinib alone (imatinib $30 \mu \mathrm{mol} / 1+$ carboplatin $7.5 \mu \mathrm{mol} / \mathrm{l})\left(\mathrm{cPDGF}-\mathrm{R} \beta_{78 \mathrm{~h}}=10 \mathrm{pg} / \mathrm{ml} / \mathrm{cPDGF}-\mathrm{R} \beta_{\text {control78h }}=\right.$ $21 \mathrm{pg} / \mathrm{ml} ; \mathrm{cPDGF}-\mathrm{R} \beta_{120 \mathrm{~h}}=0.3 \mathrm{pg} / \mathrm{ml} / \mathrm{cPDGF}-\mathrm{R} \beta_{\text {control } 120 \mathrm{~h}}=$ $8 \mathrm{p} / \mathrm{ml})(\mathrm{p}=0.2)$ (Fig. 2). For HNSCC 22B only the maximum dose of imatinib and its combination with carboplatin induced a tendency for a decreased cPDGF-R $\beta$ level in an irrelevant manner compared to controls ( $\mathrm{p}=0.32$ ) (Fig. 3). 
Table III. A, PDGF-R $\alpha$ expression in ELISA in HNSCC cell lines (pg/ml) after application of carboplatin alone and in combination with imatinib after 48 to $240 \mathrm{~h}$.

\begin{tabular}{|c|c|c|c|c|c|c|}
\hline Time of incubation (h) & Control group & $\begin{array}{c}\text { Carboplatin } \\
7.5 \mu \mathrm{mol} / 1\end{array}$ & $\begin{array}{l}\text { Imatinib } \\
18 \mu \mathrm{mol} / \mathrm{l}\end{array}$ & $\begin{array}{l}\text { Imatinib } \\
30 \mu \mathrm{mol} / 1\end{array}$ & $\mathrm{C} 3+\mathrm{I} 18$ & $\mathrm{C} 7.5+\mathrm{I} 30$ \\
\hline \multicolumn{7}{|l|}{ HNSCC 11B } \\
\hline 48 & 100.12 & 151.75 & & 136.94 & 256.23 & 174.02 \\
\hline 72 & 241.22 & 241.22 & & 188.9 & 278.77 & 308.91 \\
\hline 120 & 361.81 & 196.36 & & 166.58 & 151.75 & 196.36 \\
\hline 240 & 308.91 & 174.02 & & 107.46 & 181.46 & 218.76 \\
\hline \multicolumn{7}{|l|}{ HNSCC $14 \mathrm{C}$} \\
\hline 48 & 324.00 & 13.61 & & 813.71 & 188.90 & 301.37 \\
\hline 72 & 226.24 & 414.91 & & 20.63 & 13.61 & 6.69 \\
\hline 120 & 85.48 & 181.46 & & 0 & 27.71 & 27.71 \\
\hline 240 & 122.18 & 114.82 & & 159.16 & 49.18 & 151.75 \\
\hline \multicolumn{7}{|l|}{ HNSCC 22B } \\
\hline 48 & 159.16 & 308.91 & 331.55 & 339.11 & 354.24 & \\
\hline 72 & 0 & 316.45 & 293.83 & 339.11 & 384.55 & \\
\hline 120 & 0 & 0 & 136.94 & 34.83 & 136.94 & \\
\hline 240 & 178.16 & 20.93 & 178.16 & 20.93 & 120.00 & \\
\hline
\end{tabular}

B, PDGF-Rß expression in ELISA in HNSCC cell lines (pg/ml).

\begin{tabular}{|c|c|c|c|c|c|c|}
\hline \multicolumn{7}{|c|}{ HNSCC 11B } \\
\hline 48 & 0.63 & 10.24 & 3.56 & 3.56 & 11.20 & 4.30 \\
\hline 72 & 15.25 & 31.81 & 26.75 & 17.41 & 23.11 & 18.51 \\
\hline 120 & 27.99 & 30.52 & 71.48 & 12.18 & 21.94 & 14.21 \\
\hline 240 & 34.43 & 17.41 & 18.51 & 15.25 & 18.51 & 12.18 \\
\hline \multicolumn{7}{|c|}{ HNSCC $14 \mathrm{C}$} \\
\hline 48 & 26.75 & & & 17.41 & 18.51 & 21.94 \\
\hline 72 & 21.94 & & & 14.21 & 6.66 & 10.24 \\
\hline 120 & 8.40 & & & 0 & 0.24 & 0 \\
\hline \multicolumn{7}{|c|}{ HNSCC 22B } \\
\hline 48 & 35.70 & 45.40 & 46.90 & 55.70 & 44.00 & 37.10 \\
\hline 72 & 61.90 & 60.30 & 61.90 & 41.20 & 48.30 & 0 \\
\hline 120 & 43.00 & 42.00 & 13.10 & 0 & 7.50 & 4.20 \\
\hline 240 & 37.00 & 33.40 & 10.50 & 0 & 9.40 & 5.30 \\
\hline \multicolumn{7}{|l|}{$\mathrm{C}$} \\
\hline \multicolumn{7}{|c|}{ HNSCC $14 \mathrm{C}$} \\
\hline 0 & 20.78 & 20.78 & 20.78 & 20.78 & 20.78 & 20.78 \\
\hline 48 & 26.75 & 19.64 & 17.41 & 17.41 & 18.51 & 21.94 \\
\hline 72 & 21.94 & 29.25 & 0.24 & 14.21 & 6.66 & 10.24 \\
\hline 120 & 8.40 & 18.51 & 12.18 & 0 & 0.24 & 0 \\
\hline 240 & 2.24 & 6.66 & 8.40 & 9.31 & 12.18 & 0 \\
\hline \multicolumn{7}{|c|}{ HNSCC 22B } \\
\hline 0 & 5.84 & 5.84 & 5.84 & 5.84 & 5.84 & 5.84 \\
\hline 48 & 35.76 & 45.46 & 46.90 & 55.78 & 44.04 & 37.11 \\
\hline 72 & 61.93 & 60.37 & 61.93 & 41.23 & 48.35 & 0 \\
\hline 120 & 0 & 0 & 13.18 & 0 & 7.52 & 4.29 \\
\hline 240 & 0.79 & 4.47 & 10.52 & 0 & 9.42 & 5.37 \\
\hline
\end{tabular}

C, carboplatin; I, imatinib. Concentration: 3, 7.5 and $18 \mu \mathrm{mol} / 1$. 
Table IV. Expression of PDGF-R $\alpha$ and PDGF-Rß in HNSCC in RQ-PCR in relation $\beta$-glucuronidase (GUS) and ABL (abelson murine leukemia viral oncogene homolog).

\begin{tabular}{|c|c|c|c|c|c|c|}
\hline Time of incubation (h) & Control group & $\begin{array}{c}\text { Carboplatin } \\
7.5 \mu \mathrm{mol} / 1\end{array}$ & $\begin{array}{l}\text { Imatinib } \\
18 \mu \mathrm{mol} / 1\end{array}$ & $\begin{array}{l}\text { Imatinib } \\
30 \mu \mathrm{mol} / 1\end{array}$ & $\mathrm{C} 3+\mathrm{I} 18$ & $\mathrm{C} 7.5+\mathrm{I} 30$ \\
\hline \multicolumn{7}{|l|}{ HNSCC 11B } \\
\hline \multicolumn{7}{|l|}{ PDGF-R $\alpha /$ GUS } \\
\hline 0 & 0.05323 & 0.05323 & & 0.05323 & & 0.05323 \\
\hline 120 & 0.01438 & 0.03823 & & 0.14815 & & 0.00000 \\
\hline 240 & 0.01530 & 0.06886 & & 0.00000 & & 0.00000 \\
\hline \multicolumn{7}{|l|}{ PDGF-Rß/ABL } \\
\hline 0 & 0.522054 & & 0.522054 & 0.522054 & 0.522054 & 0.522054 \\
\hline 72 & 0.362418 & & 0.258181 & 0.106766 & 0.254031 & 0.110540 \\
\hline 120 & 0.446373 & & 0.217097 & 0.000000 & 0.140436 & 0.000000 \\
\hline \multicolumn{7}{|l|}{ UMSCC $14 \mathrm{C}$} \\
\hline \multicolumn{7}{|l|}{ PDGF-R $\alpha / G U S$} \\
\hline 0 & 0.00417 & & 0.00417 & 0.00417 & 0.00417 & 0.00417 \\
\hline 48 & 0.00318 & & 0.00098 & 0.00168 & 0.00141 & 0.00089 \\
\hline 240 & 0.00342 & & 0.00096 & 0.00096 & 0.00159 & 0.00169 \\
\hline \multicolumn{7}{|l|}{ PDGF-Rß/GUS } \\
\hline 0 & 0.039 & & 0.039 & 0.039 & 0.039 & 0.039 \\
\hline 120 & 0.133 & & 0.132 & 0.038 & 0.113 & 0.139 \\
\hline \multicolumn{7}{|l|}{ UMSCC 22B } \\
\hline \multicolumn{7}{|l|}{ PDGF-R $\alpha / G U S$} \\
\hline 0 & 0.00039 & & & 0.00039 & & 0.00039 \\
\hline 48 & 0.00056 & & & 0.00038 & & 0.00058 \\
\hline 240 & 0.00055 & & & 0.00000 & & 0.00000 \\
\hline \multicolumn{7}{|l|}{ PDGF-Rß/ABL } \\
\hline 0 & 0.082381 & & 0.082381 & 0.082381 & 0.082381 & 0.082381 \\
\hline 72 & 0.056009 & & 0.031163 & 0.019423 & 0.033968 & 0.035104 \\
\hline 120 & 0.088427 & & 0.021664 & 0.000000 & 0.073617 & 0.000000 \\
\hline 240 & 0.103772 & & 0.045745 & 0.000000 & 0.024313 & 0.000000 \\
\hline
\end{tabular}

mRNA expression of cPDGF-R $\alpha / \beta$ in HNSCC tumor cell lines. One further aim of this study was to measure the effect of the chemotherapeutic agents, as a single-active drug or in combination on PDGF-R $\alpha / \beta$ mRNA expression in HNSCC tumor cell lines 11B, 14C, 22B (in relation to the housekeeping proteins such as GUS/ABL) (Table IV).

For PDGF-R $\alpha$ of HNSCC 11B only the maximum dose of imatinib $(30 \mu \mathrm{mol} / \mathrm{l})$ and the addition of carboplatin (7.5 $\mu \mathrm{mol} / \mathrm{l})$ illustrated a verifiable effect on reduced mRNA expression after 120 and $240 \mathrm{~h}\left(\mathrm{PDGF}-\mathrm{R} \alpha / \mathrm{GUS}_{240 \mathrm{~h}}=0.0005\right.$, PDGF-R $\alpha / G_{\text {GUS }}$ control240h $\left.=0.02\right)(\mathrm{p}=0.34)$. Whereas PDGF-R $\beta$ level showed a more explicit reduction when exposed to $30 \mu \mathrm{mol} / \mathrm{l}$ imatinib (single-drug application) and when carboplatin $7.5 \mu \mathrm{mol} / 1$ is added after 120 and $240 \mathrm{~h}$, but they were not statistically significant $\left(30 \mu \mathrm{mol} / \mathrm{l}\right.$ : PDGF-Rß/GUS ${ }_{120 \mathrm{~h}}$ $=0.03, \mathrm{PDGF}-\mathrm{R} \beta / \mathrm{GUS}_{\text {control 120h }}=3.2 ; \mathrm{PDGF}-\mathrm{R} \beta / \mathrm{GUS}_{240 \mathrm{~h}}=$ $0.0008, \mathrm{PDGF}-\mathrm{RB} / \mathrm{GUS}_{\text {control240h }}=1.3 ;+7.5 \mu \mathrm{mol} / 1$ carboplatin: PDGF-Rß/GUS ${ }_{240 h}=0.0005$, PDGF-Rß/GUS $\left.{ }_{\text {control } 240 \mathrm{~h}}=1,3\right)$ $(\mathrm{p}=0.1)$. In relation to the housekeeping protein $\mathrm{ABL}$ there was a significant reduction of PDGF-Rß level after the tumor cell lines were exposed to $30 \mu \mathrm{mol} / 1$ imatinib and $7.5 \mu \mathrm{mol} / 1$ carboplatin ( $\mathrm{p}=0.001)$ (Fig. 4).

Similarly to the before mentioned ELISA, HNSCC 14C seemed to be less susceptible for a reduced PDGF-Rß level when treated with the agents, so that there was no noticeable trend in mRNA expression of PDGF-R $\beta$ versus the controls $(\mathrm{p}=0.34)$. We detected a significant depression of PDGF-R $\alpha$ when incubated with imatinib $18 \mu \mathrm{mol} / \mathrm{l}$ alone $(\mathrm{p}=0.001)$ and $30 \mu \mathrm{mol} / 1(\mathrm{p}=0.001)$ as well as the additional exposure with carboplatin 3 and $7.5 \mu \mathrm{mol} / 1$ ( $\mathrm{p}=0.001)$ (Fig. 5). This fact could also be proven in relation to ABL $(\mathrm{p}=0.014)$. Carboplatin as single-drug application had no effect in suppressing PDGF-R $\alpha$ level. HNSCC 22B complemented this hypothesis of downregulation of mRNA expression of PDGF-R $\alpha$ and -Rß/GUS by exposure of imatinib $30 \mu \mathrm{mol} / 1$ and in synergism with carboplatin $7.5 \mu \mathrm{mol} / 1$, but not statistically significant $(\mathrm{p}=0.68 ; \mathrm{p}=0.58)$. Again carboplatin showed no influence on the mRNA expression of PDGF-R when applied alone. In context to the housekeeping protein ABL we detected a significant suppressed PDGF-Rß level after the incubation with 
UMSCC-11B-PDGF-ß-ABL

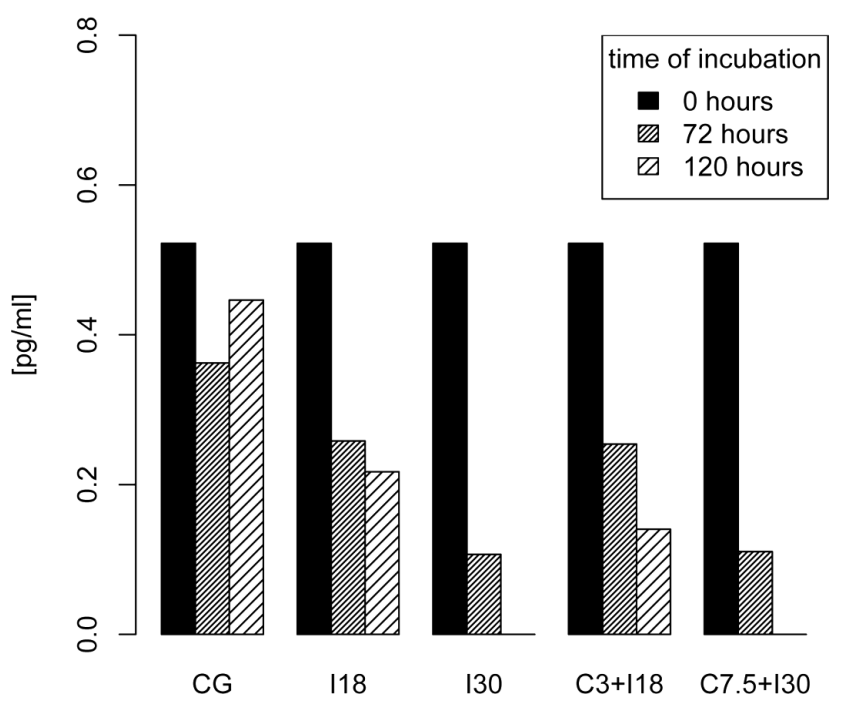

Figure 4. RQ-PCR, mRNA expression of PDGF-RB/ABL in HNSCC 11B; (C, carboplatin; I, imatinib; CG, control group). Incubation period 0-120 h $(\mathrm{p}=0.001)$.

UMSCC-22B-PDGF- $B-A B L$

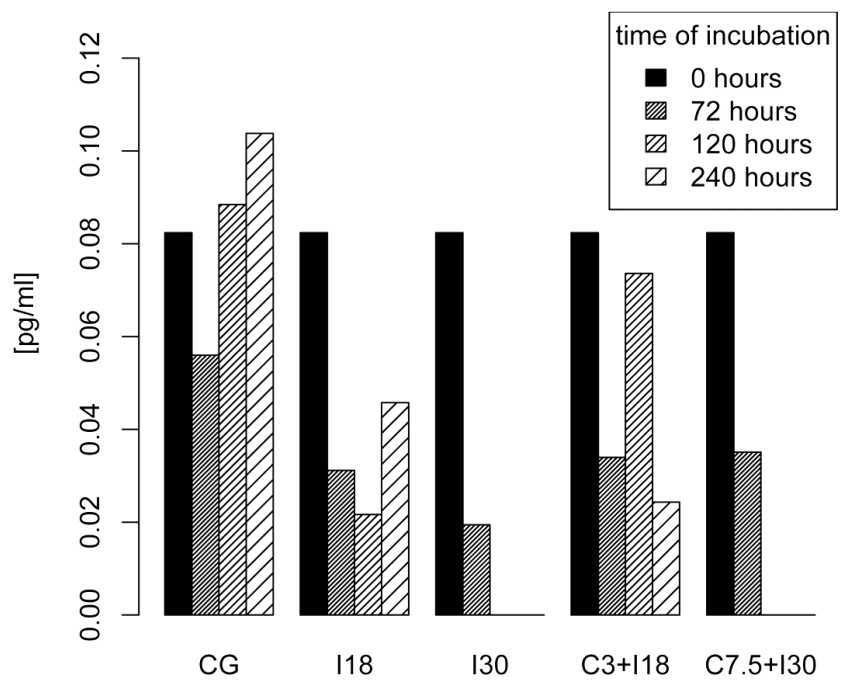

Figure 6. RQ-PCR, mRNA expression of PDGF-RB/ABL in HNSCC 22B; (C, carboplatin; I, imatinib; CG, control group). Incubation period $0-240 \mathrm{~h}$ $(\mathrm{p}=0.001)$.

imatinib $18 / 30 \mu \mathrm{mol} / \mathrm{l}$ and in the combination with carboplatin $7.5 \mu \mathrm{mol} / \mathrm{l}$ (p=0.001) (Fig. 6).

ELISA of VEGF. VEGF expression in HNSCC 11B could be significantly reduced after being incubated with imatinib $30 \mu \mathrm{mol} / 1$ and after the incubation of the combination with carboplatin $7.5 \mu \mathrm{mol} / 1$ after 120 and $240 \mathrm{~h}(\mathrm{p}=0.026)$ (after $120 \mathrm{~h}: \mathrm{cVEGF}_{\text {imatinib30 } \mu \mathrm{mol} / \mathrm{l}}=574 \mathrm{pg} / \mathrm{ml} ; \mathrm{cVEGF}_{\text {control120h }}=$ $3355 \mathrm{pg} / \mathrm{ml}$; after $240 \mathrm{~h}: \mathrm{cVEGF}_{\text {imatinib30 } \mu \mathrm{mol} / \mathrm{l}}=471 \mathrm{pg} / \mathrm{ml}$; $\mathrm{cVEGF}_{\text {control240h }}=3515 \mathrm{pg} / \mathrm{ml}$; after $120 \mathrm{~h}+7.5 \mu \mathrm{mol} / 1$ carbo-
UMSCC-14C-PDGF-a-GUS

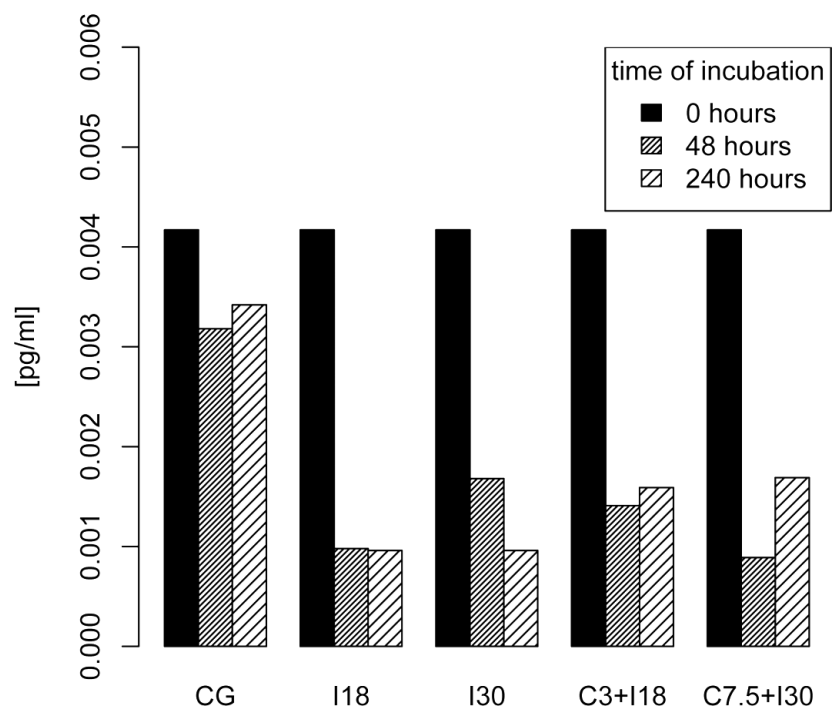

Figure 5. RQ-PCR, mRNA expression of PDGF-R $\alpha$ /GUS in HNSCC 14C; (C, carboplatin; I, imatinib; CG, control group). Incubation period 0-240 h $(\mathrm{p}=0.001)$.

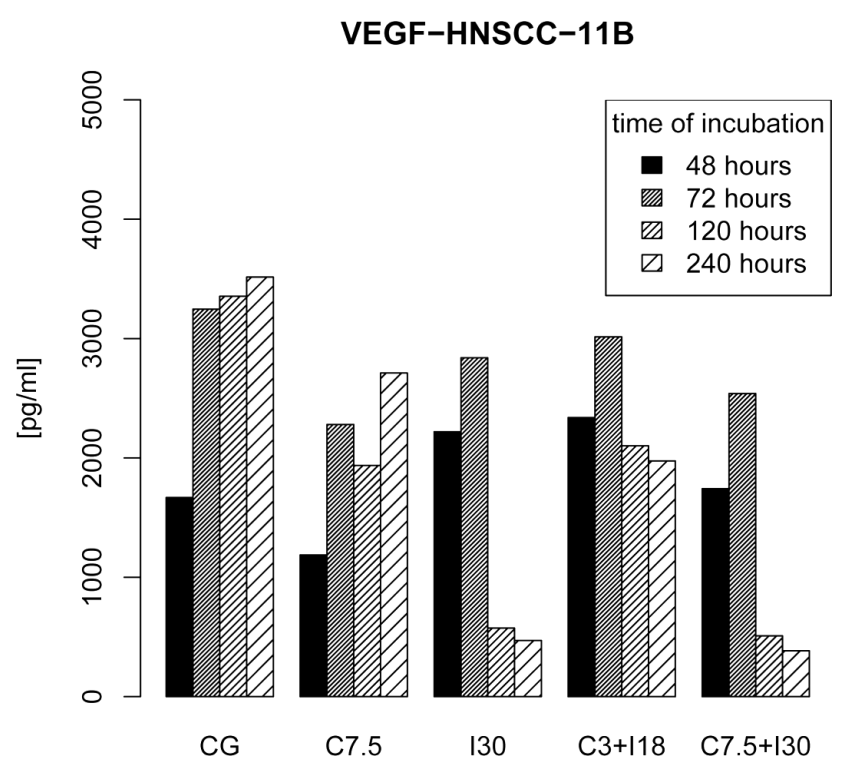

Figure 7. ELISA method; VEGF expression in HNSCC 11B. Decreased VEGF expression with rising concentrations of the applicated drugs (C, carboplatin; I, imatinib; CG, control group) after incubation periods of $0-240 \mathrm{~h}$ $(\mathrm{p}=0.026)$.

platin: $\mathrm{cVEGF}_{\text {imatinib30 } \mu \mathrm{mol} / 1}=509 \mathrm{pg} / \mathrm{ml} ; \mathrm{cVEGF}_{\text {control } 120 \mathrm{~h}}=$ $3355 \mathrm{pg} / \mathrm{ml}$, after $240 \mathrm{~h}: \mathrm{cVEGF}_{\text {imatinib30 } \mu \mathrm{mol} / \mathrm{l}}=384 \mathrm{pg} / \mathrm{ml}$, $\left.\mathrm{cVEGF}_{\text {control240h }}=3515 \mathrm{pg} / \mathrm{ml}\right)($ Fig. 7, Table V).

Effects of carboplatin, single agent, on VEGF expression was negligible. For the first time in HNSCC 14C carboplatin as a single drug at $7.5 \mu \mathrm{mol} / 1 \mathrm{had}$ a slight effect in suppressing the VEGF level. Whereas the tendency in distinct reduction of the VEGF expression was demonstrated when HNSCC $14 \mathrm{C}$ tumor cells were incubated with $30 \mu \mathrm{mol} / 1$ of imatinib (as single substance) and in combination with carboplatin 
Table V. VEGF expression in HNSCC cell lines in ELISA (pg/ml) after application of carboplatin alone and in combination with imatinib after 48 to $240 \mathrm{~h}$.

\begin{tabular}{|c|c|c|c|c|c|}
\hline Time of incubation (h) & $\begin{array}{l}\text { Control group } \\
7.5 \mu \mathrm{mol} / 1\end{array}$ & $\begin{array}{c}\text { Carboplatin } \\
30 \mu \mathrm{mol} / 1\end{array}$ & Imatinib & $\mathrm{C} 3+\mathrm{I} 18$ & $\mathrm{C} 7.5+\mathrm{I} 30$ \\
\hline \multicolumn{6}{|l|}{ HNSCC 11B } \\
\hline 48 & 1668 & 1187 & 2220 & 2338 & 1742 \\
\hline 72 & 3247 & 2280 & 2839 & 3014 & 2539 \\
\hline 120 & 3355 & 1937 & 574 & 2101 & 509 \\
\hline 240 & $>3515$ & 2711 & $471^{*}$ & 1975 & $384^{*}$ \\
\hline \multicolumn{6}{|l|}{ HNSCC 14C } \\
\hline 48 & * & 1465 & 1784 & 1747 & 1360 \\
\hline 72 & 2373 & 2605 & 3124 & 2829 & 2402 \\
\hline 120 & 2768 & 1860 & 2005 & 2717 & $817^{*}$ \\
\hline 240 & 3495 & 2496 & 2791 & 3243 & $862^{*}$ \\
\hline \multicolumn{6}{|l|}{ HNSCC 22B } \\
\hline 48 & 2916 & 2613 & 3498 & 3540 & 3303 \\
\hline 72 & $>3515$ & $>3515$ & $>3515$ & $>3515$ & $>3515$ \\
\hline 120 & 2930 & 2428 & 3269 & 1658 & 1402 \\
\hline 240 & 3368 & $>3515$ & $>3515$ & $>3515$ & 1933 \\
\hline
\end{tabular}

C, carboplatin; I, imatinib. Concentration: 3, 7.5 and $18 \mu \mathrm{mol} / \mathrm{l}$. ${ }^{*} 0 \mathrm{pg} / \mathrm{ml}$.

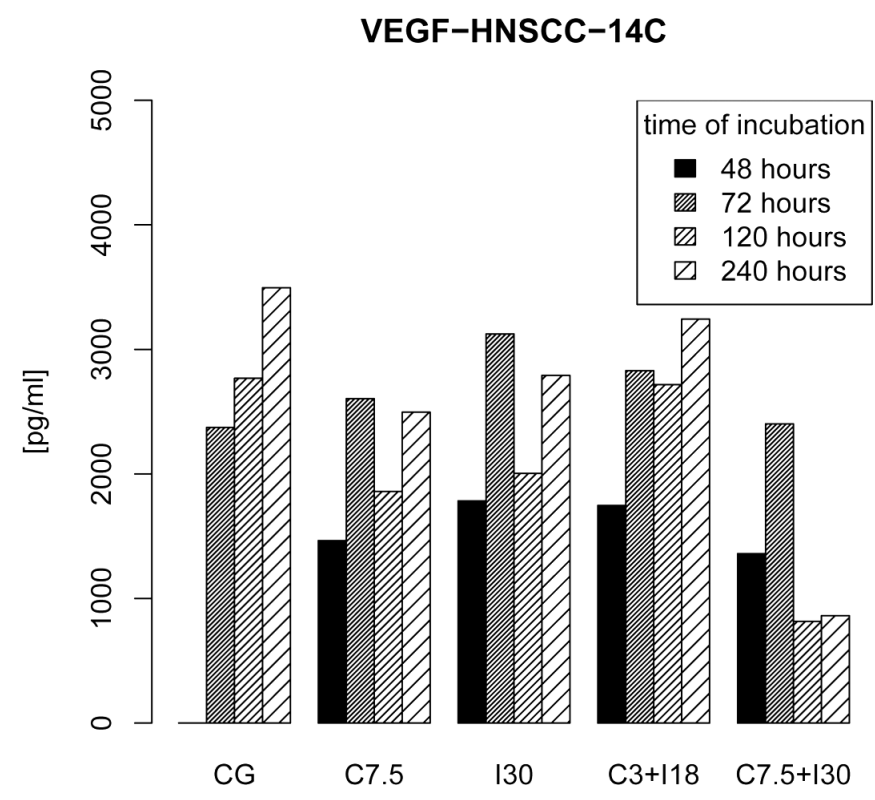

Figure 8. ELISA methods for VEGF expression in HNSCC 14C. Decreased VEGF expression with rising concentrations of the applicated drugs $(\mathrm{C}$, carboplatin; I, imatinib; CG, control group) after incubation periods of $0-240 \mathrm{~h}(\mathrm{p}=0.009)$.

$7.5 \mu \mathrm{mol} / 1$ (p=0.009) (Fig. 8). The tendency of downregulated VEGF-expression continued for HNSCC 22B, which was already illustrated above in a more moderate manner $(\mathrm{p}=0.2)$.

\section{Discussion}

Despite the therapeutic options that have been established over the last decades, HNSCC tumors are still associated with poor prognosis, emphasizing the need for new and innovative therapeutic regimens. One strategy for example is the inhibition of angiogenesis of malignant tumors. Various studies have detected an induced angiogenic response in vivo. The correlation between high microvessel counts and recurrent or metastatic disease in HNSCC, suggested a concerted interaction of stromal factors, such as VEGF, PDGF and the tumor cells. The induction of tumor vascularization is regulated by a variety of angiogenic peptides released from tumor cells into the extracellular matrix. As one of these crucial factors PDGF and the corresponding receptor PDGF-R $\alpha / \beta$ are fundamental effectors in tumor cell growth, angiogenesis and survival of the tumor $(6,8,11,13,14)$. Previous studies demonstrated the increased expression of cPDGF and the associated receptors in various malignant human tumors such as non-small cell lung (18) and prostate cancers (14). PDGF promotes the establishment of a well-vacularized stroma and hereby tumor proliferation by stimulating the angiogenesis process $(19,20)$ in melanoma (21), fibrosarcoma (22), breast carcinoma (23) and squamous carcinoma (24). VEGF, as another fundamental stimulator of angiogenesis, enhances vascular permeability (26) and is associated with an increase of tumor growth and angiogenesis in a mouse model (27). Enhanced expression of VEGF has been detected in malignant human tumors including HNSCC (28-30).

Wang-Rodriguez et al showed PDGF-R, c-kit and c-Abl overexpression in HNSCC and with functional roles in HNSCC tumor biology, making them attractive as potential clinical targets (49). There is evidence of statistically significant synergistic effects in antiproliferative impact of imatinib in conjunction with cisplatin in vitro for HNSCC $(27,41,45)$. Authors suggested that the greater sensitization to cisplatin through targeted inhibition of PTK by imatinib as an underlying mechanism, when illustrating the significantly growth inhibitory effect of the combined drug application 
(41), when both drugs are administered simultaneously. It is postulated that imatinib does not alter the PTK protein expression levels but instead influences phosphorylation and activation of PTK $(53,54)$. One explanation of synergism is the delayed DNA-crosslink adduct repair, induced by cisplatin, when exposed to imatinib; cells may undergo apoptosis due to their ability to replicate (41). Another mechanism could involve alteration of the apoptotic threshold by promoting the pro-apoptotic function of BCL-2 family regulators (46) and through this increasing the cytotoxic effect (45). However, to date the precise synergistic mechanism of imatinib in combination with cisplatin remains controversial.

The purpose of this study was to further investigate the potential synergism of imatinib and carboplatin on the expression of PDGF and PDGF-R as well as the expression of VEGF in HNSCC. We detected dose- and incubation time-dependent correlations in PDGF-R $\alpha / \beta$ level reduction in HNSCC 11B, 14C, 22B when exposed simultaneously to imatinib and carboplatin. Employing ELISA PDGF-R $\alpha / \beta$ in the different tumor cell lines showed different susceptibilities to the different chemotherapeutic drug as judged by altered PDGF-R expression levels. When imatinib was administered alone we could demonstrate a distinct trend for suppression of PDGF-receptor $\alpha / \beta$ expression. Interestingly, expression of PDGF and PDGF-R was concomitant with neoplastic progression $(12,20)$. The additional exposure of carboplatin enforces this effect in reduction of PDGF-R expression several fold but was not statistically significant in ELISA. This observation affirms the aforementioned synergism of these two different chemotherapeutic drugs, applicable for carboplatin as well as cisplatin. In contrast to Wang-Rodriguez, who described no altered PDGF-R expression, we determined an apparent reduction in PDGF-R concentration. A statistically significant correlation is proven for the reduction of normalized PDGF$\mathrm{R} \alpha / \beta$ mRNA expression for HNSCC $14 \mathrm{C}$ and 22B. Again there is evidence for the additional synergistic effect when imatinib is applied in conjunction with a platin-based chemotherapeutic drug. If administered alone, carboplatin had no influence in depressing PDGF-R expression. Restricted detection of PDGF with rising concentration of imatinib and carboplatin in immunohistochemistry and the significantly reduced VEGF-expression furthermore indicates the inhibition of the PDGF/PDGF-R autocrine tumor growth as well as the paracrine VEGF loop of imatinib (52). Comparable results were published for various other tumor entities such as neuroblastoma, where a reduction of PDGF and PDGF-R expression by imatinib leads to a suppressed VEGF concentration (55). This correlation is also being detected in ovarian cancer cells and xenograft small lung cell cancer, which illustrated that PDGF potently induce the VEGF expression, while imatinib reduced PDGF stimulated VEGF expression to basal levels $(56,57)$.

In summary, we have demonstrated the potential of carboplatin and imatinib in suppressing PDGF-receptor expression in apparently synergistic manner. In RQ-PCR statistical significance in reduction of mRNA expression of PDGF-R was detected depending on the applied chemotherapeutics and incubation time. Furthermore, there is evidence for statistically significant reduction of the VEGF expression upon incubation with carboplatin and imatinib, which affirms once again the recently published synergism of imatinib and a platin-based chemotherapy. This effect of the synergism justifies an extension of this study, eventually to an animal model. The implementation of the combination of these chemotherapeutic drugs in clinical trials could possibly enhance the efficacy of a platin-based chemotherapy as a first line standard therapy without increased toxicity profile. Further trials are necessary to affirm these results and for a more complete understanding of the mechanism and interaction concerning cellular targets in signaling pathways being affected by these drugs.

\section{Acknowledgements}

The authors would like to thank Petra Prohaska for her excellent technical assistance and Dr C. Weiss for her great assistance in statistical analysis as well as Novartis Pharma (Basel, Switzerland) for kindly providing imatinib (Gleevec).

\section{References}

1. Parkin DM, Bray F, Ferlay J, et al: Global Cancer Statistics. J Clin Cancer 55: 74-108, 2002.

2. IARC (International Agency for Research on Cancer): Globocan. www.dep.iarc.fr, 2002.

3. Ries LAG, Eisner MP, Kosary CL, et al: SEER Cancer Statistics Review: 1975-2002. National Cancer Institute, Bethesda, 2005.

4. De Wever O and Mareel M: Role of tissue stroma in cancer cell invasion. J Pathol 200: 429-447, 2003.

5. Tlsty TD and Hein PW: Know their neighbor: stromal cells can contribute oncogenic signals. Curr Opin Genet Dev 11: 54-59, 2001.

6. Bhowmick NA, Neilson EG, Moses HL, et al: Stromal fibroblasts in cancer initiation and progression. Nature 432: 332-337, 2004.

7. Bhowmick NA, Chytil A, Plieth D, et al: TGFbeta signaling in fibroblasts modulates the oncogenic potential of adjacent epithelia. Science 303: 848-851, 2004.

8. Micke P and Ostman A: Exploring the tumour environment: cancerassociated fibroblasts as targets in cancer therapy. Expert Opin Ther Targets 9: 1217-1233, 2005

9. Joyce JA: Therapeutic targeting of the tumor microenvironment. Cancer Cell 7: 513-520, 2005.

10. Hanahan D and Weinberg RA: The hallmarks of cancer. Cell 100: 57-70, 2000.

11. Park CC, Bissell MJ, Barcellos-Hoff MH, et al: The influence of the microenvironment on the malignant phenotype. Mol Med Today 6: 324-329, 2000

12. Pietras K, Sjoblom T, Rubin K, et al: PDGF receptors as cancer drug targets. Cancer Cell 3: 439-443, 2003.

13. Board R and Jayson GC: Platelet-derived growth factor receptor (PDGFR): a target for anticancer therapeutics. Drug Resist Updat 8: 75-83, 2005.

14. Heldin $\mathrm{CH}$ and Westermark B: Mechanism of action and in vivo role of platelet-derived growth factor. Physiol Rev 79: 1283-1316, 1999.

15. Betsholtz C, Karlsson L, Lindahl P, et al: Developmental roles of platelet-derived growth factors. Bioessays 23: 494-507, 2001.

16. Yu J, Ustach C and Kim HR: Platelet-derived growth factor signaling and human cancer. J Biochem Mol Biol 36: 49-59, 2003.

17. Thommen R, Humar R, Misevic G, et al: PDGF-BB increases endothelial migration on cord movements during angiogenesis in vitro. J Cell Biochen 64: 403-413, 1997.

18. Tejada ML, Yu L, Dong J, et al: Tumor-driven paracrine platelet-derived growth factor receptor alpha signaling is a key determinant of stromal cell recruitment in a model of human lung carcinoma. Clin Cancer Res 12: 2676-2688, 2006.

19. Risau W, Drexler H, Mironov V, et al: Platelet-derived growth factor is angiogenic in vivo. Growth Factors 7: 261-266, 1992

20. Pietras K, Ostman A, Sjöquist M, et al: Inhibition of plateletderived growth factor receptors reduces interstitial hypertension and increases transcapillary transport in tumors. Cancer Res 61: 2929-2934, 2001 
21. Forsberg K, Valyi-Nagy I and Heldin C-H: Platelet-derived growth factor (PDGF) in oncogenesis: development of a vascular connective tissue stroma in xenotransplanted human melanoma producing PDGF-BB. Proc Natl Acad Sci USA 90: 393-397, 1993.

22. Dong J, Grunstein J, Tejada M, et al: VEGF-null cells require PDGFR alpha signaling-mediated stromal fibroblast recruitment for tumorigenesis. EMBO J 23: 2800-2810, 2004.

23. Shao Z-M, Nguyen M, Barsky SH, et al: Human breast carcinoma desmoplasia is PDGF initiated. Oncogene 19: 4337-4345, 2000.

24. Skobe M and Fusenig NE: Tumorigenic conversion of immortal human keratinocytes through stromal cell activation. Proc Natl Acad Sci USA 95: 1050-1055, 1998.

25. Dvorak HF, Brown LF, Detmar M, et al: Vascular permeability factor/vascular endothelial growth factor, microvascular hyperpermeability and angiogenesis. Am J Pathol 146: 1029-1039, 1995.

26. Ferrara N: The role of vascular endothelial growth factor in pathological angiogenesis. Breast Cancer Res Treat 36: 127-137, 1995.

27. Zhang HT, Craft P, Scott PA, et al: Enhancement of tumor growth and vascular density by transfection of vascular endothelial cell growth factor into MCF-7 human breast carcinoma cells. Natl Cancer Inst 87: 213-219, 1995.

28. Eisma RJ, Spiro JD, Kreutzer DL, et al: Vascular endothelial growth factor expression in head and neck squamous cell carcinoma. Am J Surg 174: 513-517, 1997.

29. Mineta $\mathrm{H}$, Miura $\mathrm{K}$ and Ogino T: Prognostic value of vascular endothelial growth factor in head and neck squamous cell carcinomas. Br J Cancer 83: 775-781, 2000.

30. Salven P, Heikkilä $P$ and Anttonen A: Vascular endothelial growth factor in squamous cell head and neck carcinoma: expression and prognostic significance. Mod Pathol 10: 1128-1133, 1997.

31. Riedel F, Götte K and Schwalb J: Serum levels of vascular endothelial growth factor in patients with head and neck cancer. Eur Arch Otorhinolaryngol 257: 332-336, 2000.

32. Riedel F, Götte K and Schwalb J: Expression of vascular endothelial growth factor correlates with angiogenesis and p53 mutations in head and neck squamous cell carcinoma. Acta Otolaryngol 120: 105-111, 2000.

33. Riedel F, Götte K, Bergler W, et al: Inverse correlation of angiogenic and apoptotic markers in squamous cell carcinoma of the head and neck. Oncol Rep 8: 471-476, 2001.

34. Blume-Jensen $P$ and Hunter T: Oncogenic kinase signalling. Nature: 411: 355-365, 2001.

35. Druker BJ and Lydon NB: Lessons learned from the development of an abl tyrosine kinase inhibitor for chronic myelogenous leukemia. J Clin Invest 105: 3-7, 2000.

36. O'Dwyer ME, Mauro MJ, Druker BJ, et al: STI571 as a targeted therapy for CML. Cancer Invest 21: 429-438, 2003.

37. Roskoski R Jr: STI-571: an anticancer protein-tyrosine kinase inhibitor. Biochem Biophys Res Commun 309: 709-717, 2003.

38. Shore SK, Bogart SL, Reddy EP, et al: Activation of murine c-Abl protooncogene: effect of a point mutation on oncogenic activation. Proc Natl Acad Sci USA 87: 6502-6506, 1990.

39. Croom KF and Perry CM: Imatinib mesylate: in the treatment of gastrointestinal stromal tumours. Drugs 63: 513-522, 2003.

40. Demetri GD, von Mehren M, Blanke CD, et al: Efficacy and safety of imatinib mesylate in advanced gastrointestinal stromal tumors. N Engl J Med 347: 472-480, 2002.
41. Wang-Rodriguez J, Lopez JP and Altuna X: STI-571 (Gleevec) potentiates the effect of cisplatin in inhibiting the proliferation of head and neck squamous cell carcinoma in vitro. Laryngoscope 116: 1409-1416, 2006

42. Kano Y, Akutsu M, Tsunoda S, et al: In vitro cytotoxic effects of a tyrosine kinase inhibitor STI571 in combination with commonly used antileukemic agents. Blood 97: 1999-2007, 2001.

43. Faivre $\mathrm{S}$, Raymond $\mathrm{E}$, Casiraghi $\mathrm{O}$, et al: Imatinib mesylate can induce objective response in progressing, highly expressing KIT adenoid cystic carcinoma of the salivary glands. J Clin Oncol 23: 6271-6273, 2001.

44. Zhang P, Gao WY, Turner S and Ducatman B: Gleevec (STI 571) inhibits lung cancer cell growth (A549) and potentiates the cisplatin effect in vitro. Mol Cancer 2: 1-9, 2003.

45. Bruce IA, Slevin NJ, Homer JJ, McGown AT and Ward TH: Synergistic effects of imatinib (STI 571) in combination with chemotherapeutic drugs in head and neck cancer. Anticancer Drugs 16: 719-726, 2005.

46. Bellone G, Ferrero D, Carbone A, et al: Inhibition of cell survival and invasive potential of colorectal carcinoma cells by the tyrosine kinase inhibitor STI 571. Cancer Biol Ther 3: 385-392, 2004.

47. Pietras K, Rubin K, Sjoblom T, et al: Inhibition of PDGF receptor signaling in tumor stroma enhances antitumor effect of chemotherapy. Cancer Res 62: 5476-5484, 2002.

48. Fan S, el-Deiry WS, Bae I, et al: p53 gene mutations are associated with decreased sensitivity of human lymphoma cells to DNA damaging agents. Cancer Res 54: 5824-5830, 1994.

49. Gong B and Almasan A: Differential upregulation of p53-responsive genes by genotoxic stress in hematopoietic cells containing wild-type and mutant p53. Gene Expr 8: 197-206, 1999.

50. Erben P, Gosenca D, Müller MC, et al: Screening for diverse PDGFRA or PDGFRB fusion genes is facilitated by generic quantitative reverse transcriptase polymerase chain reaction analysis. Haematologica 95: 738-744, 2010.

51. Muller MC, Erben P, Saglio G, et al: Harmonization of BCR-ABL mRNA quantification using a uniform multifunctional control plasmid in 37 international laboratories. Leukemia 22: 96-102, 2008.

52. Bran B, Bran G, Hörmann K, et al: The platelet-derived growth factor receptor as a target for vascular endothelial growth factormediated anti-angiogenetic therapy in head and neck cancer. Int J Oncol 34: 255-261, 2009.

53. Kitamura Y and Hirotab S: Kit as a human oncogenic tyrosine kinase. Cell Mol Life Sci 61: 2924-2931, 2004.

54. Bishayee S, Ross AH, Womer R, et al: Purified human plateletderived growth factor receptor has ligand-stimulated tyrosine kinase activity. Proc Natl Acad Sci USA 83: 6756-6760, 1986.

55. Beppu K, Jaboine J, Merchant MS, et al: Effect of imatinib mesylate on neuroblastoma tumorigenesis and vascular endothelial growth factor expression. J Natl Cancer Inst 96: 46-55, 2004.

56. Matei D, Kelich S, Cao L, et al: PDGF BB induces VEGF secretion in ovarian cancer. Cancer Biol Ther 6: 1951-1959, 2007.

57. Vlahovic G, Ponce AM, Rabbani Z, et al: Treatment with imatinib improves drug delivery and efficacy in NSCLC xenografts. Br J Cancer 97: 735-740, 2007. 